\title{
Respiratory Viruses in the Pediatric Intensive Care Unit Prevalence and Clinical Aspects
}

\author{
Selir M Straliotto/ ${ }^{+}$, Marilda M Siqueira*, Vera Machado**, Tânia MR Maia***
}

Fundação Estadual de Produção e Pesquisa em Saúde, Seção de Virologia do Laboratório Central de Saúde Pública, Av. Ipiranga 5400, 90610-000 Porto Alegre, RS, Brasil *Departamento de Virologia, Instituto Oswaldo Cruz-Fiocruz, Rio de Janeiro, RJ, Brasil **Hospital Nossa Senhora da Conceição, Comissão de Infecção Hospitalar, Porto Alegre, RS, Brasil ***Hospital da Criança Santo Antônio/ISCMPA, Unidade de Tratamento Intensivo, Porto Alegre, RS, Brasil

A survey was conducted in two pediatric intensive care units in hospitals in Porto Alegre, Brazil, in order to monitor the main respiratory viruses present in bronchiolitis and/or pneumonia and their involvement in the severity of viral respiratory infections. Viral respiratory infection prevalence was $38.7 \%$. In bronchiolitis, respiratory syncytial virus (RSV) was detected in $36 \%$ of the cases. In pneumonia, the prevalence rates were similar for adenovirus (10.3\%) and RSV (7.7\%). There was a difference among the viruses detected in terms of frequency of clinical findings indicating greater severity. Frequency of crackles in patients with RSV (47.3\%) showed a borderline significance ( $p=0.055$. Fisher's exact test) as compared to those with adenovirus $(87.5 \%)$. The overall case fatality rate in this study was $2.7 \%$, and adenovirus showed a significantly higher case fatality rate (25\%) than RSV (2.8\%) ( $p=0.005)$. Injected antibiotics were used in $49 \%$ of the children with RSV and $60 \%$ of those with adenovirus. Adenovirus was not detected in any of the 33 children submitted to oxygen therapy.

Key words: respiratory syncytial virus - adenovirus - bronchiolitis - pneumonia - viral respiratory infection

Frequency of viral detection in acute respiratory infections (ARI) depends on many factors, such as patient selection criteria, disease severity, season of the year, and diagnostic method. The first prevalence study of viral ARI in pediatric patients in Porto Alegre, state of Rio Grande do Sul, Brazil, from 1990 to 1992, showed the highest prevalence of viral infections in the winter months in emergency care services $(53 \%)$ and in hospitalized patients $(42.3 \%)$. The main viral etiologic agent detected was respiratory syncytial virus (RSV), which was also mainly responsible for cases of bronchiolitis. Adenovirus was the main etiologic agent for pneumonia in 1992 (20\%). The influenza and parainfluenza viruses showed low pediatric prevalence rates from 1990 to 1992 in Porto Alegre (Straliotto et al. 2002).

Among children, RSV infection is the cause of 50 to $90 \%$ of hospitalizations for bronchiolitis and 5 to $40 \%$ for pneumonia (Hall 2001). RSV is considered the main agent responsible for infant deaths during the winter (Anderson et al. 1990). RSV re-infection is extremely common, with frequent spread to family and hospital contacts (Nosocomial 1992), hence posing a major risk to uninfected hospitalized children during an outbreak (Madge et al. 1992).

Adenovirus is the second most common virus detected in children hospitalized with ARI. Some adenovirus serotypes have been reported in severe disease, causing infant death by pneumonia or necrotizing bronchiolitis

${ }^{+}$Corresponding author. Fax: +55-51-32884019. E-mail: smstra@bol.com.br

Received 3 June 2004

Accepted 10 November 2004
(Kajon et al. 1996, Videla et al. 1998). According to Cherian et al. (1988), the strongest indicator of severity in ARI is a respiratory rate greater than 50 breaths/min for children less than 12 months of age and greater than 40 breaths/ min for children from 12 to 35 months. Other important indicators include a history of tachypnea and presence of chest wall retraction. In acute bronchiolitis, clinical signs indicative of severity include cyanosis, crackles, and oxygen saturation $\left(\mathrm{SaO}_{2}\right)$ (Mulholland et al. 1990). Respiratory support measures such as oxygen therapy, bronchodilators, corticosteroids, and mechanical ventilation have also been included to evaluate clinical severity. Mechanical ventilation is used in acute lower respiratory tract infection (ALRTI) when respiratory failure and apnea occur (Hall \& McCarthy 1995).

In order to monitor the main respiratory viruses present in ALRTI in the pediatric intensive care units (ICU) and their involvement in the severity of viral respiratory infections, we conducted a survey in two hospitals in Porto Alegre from June to December 1996.

\section{MATERIALSAND METHODS}

A total of 261 children under 7 years of age were with a clinical diagnosis of pneumonia and/or bronchiolitis, admitted to the pediatric ICU in Hospital Nossa Senhora da Conceição (HNSC) and Hospital da Criança Santo Antônio (HCSA), from June to December 1996.

Pneumonia was defined as viral or bacterial disease characterized by fever, cough, moaning, rales, tachypnea, subcostal rectration, cyanosis, bronchophony, with or without ventilatory pain, associated with consolidation in a radiologic exam; and bronchiolitis, a viral disease characterized by a first episode of cough, tachypnea, subcostal retraction, wheezing, moaning, fever, in a child under one year of age.

To evaluate clinical severity, we considered the pres- 
ence of at least one of the following clinical findings, indicative of ARI severity: tachypnea, respiratory rate $(\geq 50$ breaths/min for less than 12 months of age and $\geq 40$ breaths/min for 12 to 35 months), chest wall retraction, crackles, and cyanosis (Cherian et al. 1988, Mulholland et al. 1990). Evaluation of clinical severity also included use of therapeutic support measures such as oxygen therapy, bronchodilators, corticosteroids, and mechanical ventilation.

Children included in the study were submitted to a thorough case history and physical examination. An epidemiological form was filled out for clinical and therapeutic data collection. Verbal consent was obtained from parents before clinical sample collection.

Viral antigens (RSV, adenovirus, influenza A and B, and parainfluenza type 3 ) were detected directly in nasopharyngeal secretion (NPS) using an indirect fluorescent antibody test (IFAT) with commercial monoclonal antibodies (Chemicon International, Inc.).

Statistical analysis - Statistical analysis was performed using the chi-squared test, and when necessary Yates' correction and Fisher's exact test.

\section{RESULTS}

Our study showed a viral respiratory infection prevalence of $38.7 \%$ (101/261), with RSV accounting for $27.2 \%$ (71/261), adenovirus $7.7 \%$ (20/261), parainfluenza virus type $32.3 \%$ (6/261), and influenza A virus 1.5\% (4/261). No case of influenza B virus was detected during the study period.

Of the 39 samples with a clinical diagnosis of pneumonia, some type of virus was detected in $25.6 \%$ (10), and prevalence rates were similar for adenovirus $(10.3 \%)$ and RSV $(7.7 \%)$. Of the 139 cases of bronchiolitis in which a viral pathogen was detected $(44.6 \%), 36 \%$ were caused by RSV and $4.3 \%$ by adenovirus. In the samples with a diagnosis of pneumonia and bronchiolitis, RSV (22.1\%) and adenovirus (13\%) were also the most frequently detected viral agents (Table I).

Clinical findings indicative of greater clinical severity, i.e., tachypnea, respiratory rate as defined above and chest wall retraction were found in $94.2 \%, 94.7 \%$, and $97.7 \%$ of pediatric ICU patients, respectively, while crackles and cyanosis were found in $50 \%$ and $57.9 \%$ of cases, respectively (Table II). There was no difference among the viruses detected in terms of frequency of clinical findings indicating greater severity, except for crackles. The difference in frequency of crackles in patients with RSV $(47.3 \%)$ and adenovirus (87.5\%) showed a borderline significance ( $\mathrm{p}=0.055$ Fisher's exact test). Percentages of this finding among cases with and without viral detection were $45.8 \%$ and $54.2 \%$, respectively.

Of the children from our study who died from pneumonia and/or bronchiolitis and with viral detection by IFAT, one had underlying heart disease and two had associated sepsis. The overall case fatality rate in this study was $2.7 \%$ (7/261). Of these cases, adenovirus was detected in 5 clinical samples $(1.9 \%)$ and RSV in 2 samples $(0.8 \%)$. Of the adenovirus cases, the case fatality rate of $25 \%$ $(5 / 20)$ was statistically higher than the $2.8 \%$ rate $(2 / 70)$ among RSV cases ( $\mathrm{p}=0.005$ Fisher's exact test) (Table II).

As for therapeutic measures, $49 \%$ of children with RSV and $60 \%$ of those with adenovirus received injected antibiotics, which were used in $60.5 \%$ of all the patients studied. Corticosteroid therapy was used in $40 \%$ of patients with adenovirus respiratory infection. Some $30 \%$ of children with adenovirus and $8 \%$ of those with RSV required mechanical ventilation. Adenovirus was not detected in any of the 33 children submitted to oxygen therapy (Table III).

\section{DISCUSSION}

Previous studies have demonstrated that respiratory viruses circulate in Porto Alegre mainly during winter months (July to September) (Straliotto et al. 2002). From June to December 1996, the two main viruses detected in acute lower respiratory tract infection (ALRTI) in the pediatric ICUs in two Porto Alegre hospitals were RSV $(26.8 \%)$ and adenovirus $(7.7 \%)$. These two have also been reported as the most frequent viral pathogens in studies on hospitalized children with ALRTI in other countries of the southern cone of South America, like Argentina (Àvila et al. 1990, Savy et al. 1996, Videla et al. 1998) and Uruguay (Russi 1992).

A study on child mortality due to ALRTI in patients under 5 years of age reported a $3.8 \%$ rate (Carballal et al. 1990). This rate increases with viral respiratory etiology in patients with immune suppression, transplants, or car-

TABLE I

Prevalence of lower respiratory tract viral infection in pediatric intensive care units patients $(\mathrm{n}=261)$

\begin{tabular}{|c|c|c|c|c|c|c|c|}
\hline \multirow{2}{*}{$\begin{array}{l}\text { Clinical } \\
\text { diagnosis }\end{array}$} & \multirow{2}{*}{$\mathrm{n}$} & \multirow{2}{*}{$\begin{array}{l}\text { Positive } \\
\text { samples } \\
\text { n }(\%)\end{array}$} & \multicolumn{4}{|c|}{ Virus detected n (\%) } & \multirow{2}{*}{$\begin{array}{c}\text { Deaths } \\
\text { n }\end{array}$} \\
\hline & & & RSV & Adeno & Flu A & PF3 & \\
\hline Pneumonia & 39 & $10(25.6)$ & $3(7.7)$ & $4(10.3)$ & $1(2.6)$ & $2(5.1)$ & $1^{a}$ \\
\hline Bronchiolitis & 139 & $62(44.6)$ & $50(36.0)$ & $6(4.3)$ & $4(2.9)$ & $2(1.4)$ & $3^{a, \mathrm{~b}}$ \\
\hline Pneum/Bronch. & 77 & $28(36.4)$ & $17(22.1)$ & $10(13.0)$ & $1(1.3)$ & 0 & $3^{a}$ \\
\hline No diagnosis & 6 & $1(16.7)$ & $1(16.7)$ & 0 & 0 & 0 & \\
\hline Total & 261 & $\begin{array}{l}101 \\
38.7 \%\end{array}$ & $\begin{array}{l}71 \\
27.2 \%\end{array}$ & $\begin{array}{l}20 \\
7.7 \%\end{array}$ & $\begin{array}{l}6 \\
2.3 \%\end{array}$ & $\begin{array}{l}4 \\
1.5 \%\end{array}$ & $\begin{array}{l}7 \\
2.7 \%\end{array}$ \\
\hline
\end{tabular}

Of all samples, 6 lacked data on the clinical diagnosis; (\%) percentage of virus detected by clinical diagnosis; $a$ : adenovirus (5) - case fatality $1.9 \%$; $b$ : respiratory syncytial virus (2) - case fatality $0.8 \%$. 
TABLE II

Clinical features and viral detection in intensive care units patients with acute lower respiratory tract infection

\begin{tabular}{|c|c|c|c|c|}
\hline \multirow[b]{2}{*}{ Feature } & \multirow[b]{2}{*}{ RSV } & \multicolumn{2}{|c|}{ Etiologic diagnosis $(\mathrm{nr} / \mathrm{n})$} & \multirow[b]{2}{*}{ Negative case } \\
\hline & & Adenovirus & $\begin{array}{c}\% \\
\text { Other viruses }\end{array}$ & \\
\hline \multirow[t]{2}{*}{ Tachypnea $(\mathrm{N}=257)$} & $65 / 70$ & $19 / 20$ & $10 / 10$ & $148 / 242$ \\
\hline & $92.9 \%$ & $95 \%$ & $100 \%$ & $61.2 \%$ \\
\hline \multirow{2}{*}{ Respiratory rate $^{a}(\mathrm{~N}=208)$} & $57 / 62$ & $11 / 11$ & $5 / 5$ & $124 / 197$ \\
\hline & $92 \%$ & $100 \%$ & $100 \%$ & $62.9 \%$ \\
\hline \multirow[t]{2}{*}{ Chest wall retraction $(\mathrm{N}=260)$} & $69 / 71$ & $19 / 20$ & $10 / 10$ & $156 / 254$ \\
\hline & $97.2 \%$ & $95 \%$ & $100 \%$ & $61.4 \%$ \\
\hline \multirow[t]{2}{*}{ Crackles $^{b}(\mathrm{~N}=118)$} & $18 / 38$ & $7 / 8$ & $2 / 2$ & $32 / 59$ \\
\hline & $47.3 \%$ & $87.5 \%$ & $100 \%$ & $54.2 \%$ \\
\hline \multirow[t]{2}{*}{ Cyanosis $(\mathrm{N}=247)$} & $42 / 68$ & $10 / 18$ & $7 / 10$ & $84 / 143$ \\
\hline & $61.8 \%$ & $55.6 \%$ & $70 \%$ & $58.7 \%$ \\
\hline \multirow[t]{2}{*}{ Fatal outcome $(\mathrm{N}=261)$} & $2 / 71$ & $5 / 20$ & 0 & 0 \\
\hline & $2.8 \%$ & $25 \%$ & & \\
\hline
\end{tabular}

$a$ : respiratory rate corresponds to 50 breaths/min for children under 12 months and 40 breaths/min from 12 to 35 months. $b$ : in 143 patients there was no information on presence of crackles; nr: corresponds to number of cases with viral etiologic diagnosis (by type of virus or absence thereof) with presence of clinical findings; n: corresponds to number of cases with viral etiologic diagnosis (by type of virus or absence thereof) with presence or absence of clinical findings; N: corresponds to total number of cases with data on clinical findings (presence or absence).

\section{TABLE III}

Frequency of use of therapeutic measures and viruses detected in pediatric intensive care units patients with lower respiratory tract illness $(\mathrm{n}=261)$

\begin{tabular}{|c|c|c|c|c|c|c|}
\hline \multirow{2}{*}{$\begin{array}{l}\text { Therapeutic } \\
\text { measures }\end{array}$} & \multicolumn{2}{|c|}{ Frequency } & \multicolumn{4}{|c|}{ Virus detected n (\%) } \\
\hline & $\mathrm{n}$ & $\%$ & $\begin{array}{c}\text { RSV } \\
\mathrm{n}=71\end{array}$ & $\begin{array}{l}\text { Adeno } \\
\mathrm{n}=20\end{array}$ & $\begin{array}{l}\text { Flu A } \\
\mathrm{n}=6\end{array}$ & $\begin{array}{c}\text { PF3 } \\
n=4\end{array}$ \\
\hline Nose drops/saline & 57 & 21.8 & $21(30)$ & $3(15)$ & $1(17)$ & 0 \\
\hline Oral antibiotics & 25 & 9.6 & $5(10)$ & 0 & $2(33)$ & 0 \\
\hline Inject. antibiotics & 158 & 60.5 & $35(49)$ & $12(60)$ & $2(33)$ & $1(25)$ \\
\hline Antipyretics & 102 & 39.1 & $31(44)$ & $7(35)$ & $1(17)$ & $2(50)$ \\
\hline Spray bronchod. & 124 & 47.5 & $35(49)$ & $6(30)$ & 0 & $2(50)$ \\
\hline Oral bronchod. & 73 & 28.0 & $16(23)$ & $10(50)$ & $3(50)$ & $2(50)$ \\
\hline Oxygen therapy & 33 & 12.6 & $11(15)$ & 0 & $1(17)$ & $1(25)$ \\
\hline Mechanical vent. & 25 & 9.6 & $6(8)$ & $6(30)$ & $1(17)$ & 0 \\
\hline Corticosteroid & 84 & 32.2 & $18(25)$ & $8(40)$ & $1(17)$ & $1(25)$ \\
\hline
\end{tabular}

Patients used more than one type of medication simultaneously.

diac disease (Moler et al. 1992, Pham et al. 2003, Raboni et al. 2003). Overall case fatality in hospitalized children with acute lower respiratory infection due to RSV and adenovirus in Argentina was $2.4 \%$. Adenovirus was detected in the nasopharyngeal aspirate in all the fatal cases, and the case fatality rate among patients with adenovirus was $16.7 \%$ (Videla et al. 1998). Our study also showed a high case fatality rate for adenovirus $(25 \%)$, yet different from that of RSV $(2.8 \%)$. However, the latter rate is consistent with other studies on case fatality for RSV, showing rates varying from 0 to $6 \%$, reviewed by Weber et al. (1998). RSV case fatality rates increase significantly in children with pulmonary, congenital heart, and other chronic diseases (Navas et al. 1992). Of the children from our study who died from pneumonia and/or bronchiolitis and with viral detection by IFAT, one had underlying heart disease and two had associated sepsis. There is a need for further research to clarify case fatality in respiratory diseases involving viral pathogens and to identify the genome viruses' community.

The analysis of clinical findings indicative of greater clinical severity suggests that the presence of crackles in children in the ICU may be a prognostic factor in adenovirus infection. However, further studies are necessary to allow such a conclusion.

Although bronchodilators are frequently used, data on their efficacy are conflicting. While Hammer et al. (1995) observed a limited effect on patients with severe RSV infection, other studies have indicated their safety and efficacy in relieving respiratory distress (Klassen et al. 1991, Alario et al. 1992). Use of parenteral antibiotics, especially for 5 days or more, appears to increase the risk of secondary bacterial infection in a few infants, which is low in most infants with RSV infection (Hall et al. 1988). However, our study pointed to high frequency in the use of injected antibiotics $(60.5 \%)$, both with adenovirus $(60 \%)$ 
and RSV (50\%) detections. The same was not true for oral antibiotics, with a lower rate $(9.6 \%)$. Corticosteroids are commonly prescribed for treating RSV bronchiolitis (Kimpen \& Schaad 1997), but no study has proven their therapeutic efficacy (Dabbous et al. 1988, Klassen et al. 1997). In our study, corticosteroids were prescribed for $40 \%$ of children with adenovirus and $26 \%$ with RSV. Oxygen therapy, another important support measure for RSV lower respiratory tract infections (Ellis 1986), was used in $12.6 \%$ of our cases, including $16 \%$ of the group with RSV detection and none of those with adenovirus. However, greater need for additional oxygen $(\mathrm{p}<0.2)$ for children shedding Ad genome type $7 \mathrm{~h}$ was verified during adenovirus surveillance through 8 years in Chile (Larranaga et al. 2000). Rapid progression of the clinical course despite antibiotic therapy and the presence of unusual extrapulmonary symptoms are important clinical clues in the diagnosis of severe adenovirus infection. The clinical, laboratory, and radiographic features of severe adenovirus infection in children may mimic bacterial infection (Chuang et al. 2003).

According to our study, RSV and adenovirus are important viral etiologic agents for bronchiolitis and pneumonia in pediatric ICU patients. This poses a serious problem for pediatric ICU, since seriously ill patients are at greater risk of acquiring hospital infections. Respiratory viruses were implicated in $61 \%$ of nosocomial respiratory infections for which an etiologic diagnosis was established (Welliver \& McLaughlin 1984), especially RSV (Editorial 1992). Some adenovirus genomic serotypes have shown a high secondary attack rate, emphasizing the importance of adequate isolation of patients and the need for rapid and sensitive viral diagnosis (Palomino et al. 2000, Mitchell et al. 2000).

Monitoring respiratory viruses involved in ARI, especially in the pediatric ICU, improves the orientation of therapeutic and preventive measures, avoids unnecessary use of antibiotics, and helps control hospital infection.

\section{ACKNOWLEDGEMENTS}

To Dr João Carlos Batista Santana (SES/RS) and Sandra A Nestor (LACEN/FEPPS), for their skillful collaboration; and to Vânia Naomi Hirakata (SES/RS) for her helpful statistical analysis.

\section{REFERENCES}

Alario AJ, Lewander WJ, Dennehy P, Seifer R, Mansell AL 1992. The efficacy of nebulized metaproterenol in wheezing infants and young children. AJDC 146: 412-418.

Anderson LJ, Parker RA, Strikas RL 1990. Association between respiratory syncytial virus outbreaks and lower respiratory tract deaths of infants and young children. $J$ Infect Dis 161: 640-646.

Àvila M, Salomón H, Carballal G, Ebekian B, Woyskovsky N, Cerqueiro MC, Weissenbacher M 1990. Role of viral pathogens in acute respiratory tract infections. Rev Infect Dis 12: S974-S981.

Carballal G, Siminovich M, Murtagh P, Cerqueiro MC, Àvila M, Salomón H, Catalano M, Weissenbacher M 1990. Etiologic, clinical, and pathologic analysis of 31 fatal cases of acute respiratory tract infection in Argentinian children under 5 years of age. Rev Infect Dis 12(Supp. 8): 1074-1080.
Chuang YY, Chiu CH, Wong KS, Huang JG, Huang YC, Chang LY, Lin TY 2003. Severe adenovirus infection in children. $J$ Microbiol Immunol Infect 36: 37-40.

Cherian T, John TJ, Simões E, Steinhoff MC, John M 1988. Evaluation of simple clinical signs for the diagnosis of acute lower respiratory tract infection. The Lancet 16: 125-126.

Dabbous IA, Tkachyk JS, Stamm SJ 1988. A double blind study on the effects of corticosteroids in the treatment of bronchiolitis. Pediatrics 37: 477-484.

Editorial 1992. Nosocomial infection with respiratory syncytial virus. The Lancet 340: 1071-1072.

Ellis EF 1986. Prevention and treatment of respiratory infectious diseases, particularly bronchiolitis. Therapy of acute bronchiolitis. Pediatr Res 17: 2386-2388.

Hall CB 2001. Respiratory syncytial virus and parainfluenza virus. New Engl J Med 344: 1917-1928.

Hall CB, McCarthy CA 1995. Respiratory syncytial virus. In GL Mandell, RG Douglas, JE Bennett (eds), Principles and Practice of Infectious Diseases, 4th ed., Churchill Livingstone, New York, p. 1501-1519.

Hall CB, Powell KR, Schnabel KC, Gala CL, Pincus PH 1988. Risk of secondary bacterial infection in infants hospitalized with respiratory syncytial viral infection. J Pediat 113: 266-271.

Hammer J, Numa A, Newth CJL 1995. Albuterol responsiveness in infants with respiratory failure caused by respiratory syncytial virus infection. J Pediatr 127: 485-490.

Kajon AE, Mistchenko AS, Videla C, Hortal M, Wadell G, Avedaño LF 1996. Molecular epidemiology of adenovirus acute lower respiratory infections of children in the south cone of South America (1991-1994). J Med Virol 48: 151156.

Kimpen JLL, Schaad UB 1997. Treatment of respiratory syncytial virus bronchiolitis: 1995 poll of members of European Society for Paediatric Infectious Diseases. Pediatr Infect Dis J 16: 479-481.

Klassen TP, Rowe PC, Sutcliffe T, Ropp LJ, McDowwell IW, Li MM 1991. Randomized trial with salbutamol in acute bronchiolitis. J Pediatr 118: 807-811.

Klassen TP, Sutcliffe T, Watters LK, Wells GA, Allen UD, Li MM 1997. Dexamethasone in salbutamol-treated inpatients with acute bronchiolotis: a randomized, controlled trial. J Pediatr 130: 191-196.

Larranaga C, Kajon A, Villagra E, Avendano LF 2000. Adenovirus surveillance in children hospitalized for acute lower respiratory infections in Chile (1988-1996). J Med Virol 60: 342-346.

Madge P, Paton JY, McColl JH, Mackie PLK 1992. Prospective controlled study of four infection-control procedures to prevent nosocomial infection with respiratory syncytial virus. The Lancet 340: 1079-1083.

Mitchell LS, Taylor B, Reimels W, Barrett FF, Devincenzo JP 2000. Adenovirus 7a: a community-acquired outbreak in a children's hospital. Pediatr Infect Dis J 19: 996-1000.

Moler FW, Khan AS, Meliones JN, Custer JR, Palmisano J, Shope TC 1992. Respiratory Syncytial Virus morbidity and mortality estimates in congenital heart disease patients: a recent experience. Crit Care Med 20: 1406-1413.

Mulholland EK, Olinsky A, Shann FA 1990. Clinical findings and severity of acute bronchiolitis. The Lancet 335: 12591261.

Navas L, Wang E, de Carvalho V, Robinson J, and Pediatric Investigators Collaborative Network on Infections in Canada 1992. Improved outcome of respiratory syncytial virus infection in a high-risk hospitalized population of Canadian children. J Pediatr 121: 328-354.

Palomino MA, Larranaga C, Avendano LF 2000. Hospital-ac- 
quired adenovirus $7 \mathrm{~h}$ infantile respiratory infection in Chile. Pediatr Infect Dis 19: 527-531.

Pham TT, Burchette Jr JL, Hale LP 2003. Fatal disseminated adenovirus infection in immunocompromised patients. Am J Clin Pathol 120: 575-583.

Raboni SM, Nogueira MB, Tsuchiya LR, Takahashi GA, Pereira LA, Pasquini R, Siqueira MM 2003. Respiratory tract viral infection in bone marrow transplant patients. Transplantation 76: 142-146.

Russi JC 1992. Diagnóstico virológico de infecciones respiratorias agudas del niño menor de 5 años, 1991. Bol Latinoam 1: 7.

Savy V, Baumeister E, Bori F, Shiroma M, Campos A 1996. Evaluación etiologica y clínica de infecciones respiratorias agudas bajas en una población infantil. Medicina 56: 213-
217.

Straliotto SM, Siqueira MM, Muller RL, Fischer GB, Cunha MLT, Nestor SM 2002. Viral etiology of acute respiratory infections among children in Porto Alegre, RS, Brazil. Rev Soc Bras Med Trop 35: 283-291.

Videla C, Carballal G, Misirlian A, Aguilar M 1998. Acute lower respiratory infections due to respiratory syncytial virus and adenovirus among hospitalized children from Argentina. Clin Diag Virol 10: 17-23.

Weber MW, Mulholland EK, Greenwood BM 1998. Respiratory syncytial virus infection in tropical and developing countries. Trop Med Int Health 3: 268-280.

Welliver RC, McLaughlin S 1984. Unique epidemiology of nosocomial infection in a children's hospital. Am J Dis Child 138: 131-135. 
